\title{
RADIOCARBON IN POREWATER OF CONTINENTAL SHELF SEDIMENTS (SOUTHEAST MEDITERRANEAN)
}

\author{
O Sivan $^{1,2,3} \cdot$ B Lazar $^{1} \bullet$ E Boaretto $^{4} \cdot \mathrm{Y} \mathrm{Yechieli}^{2} \cdot$ B Herut $^{5}$
}

ABSTRACT. In this study, we aim to characterize the main processes controlling ${ }^{14} \mathrm{C}_{\mathrm{DIC}}$ concentrations in porewater at the shallow shelf (water depth less than $120 \mathrm{~m}$ ) off the Mediterranean coast of Israel. At these water depths, we expected to find evidence for seawater penetration toward the coast, since this area was flooded by seawater only some 18,000 yr ago (the end of the Last Glacial period).

Measurements of the chemical composition $\left({ }^{14} \mathrm{C}_{\mathrm{DIC}}\right)$ and stable carbon isotopic composition $\left(\delta^{13} \mathrm{C}_{\mathrm{DIC}}\right)$ were performed in several sediment cores (40-250 cm long) at water depths between 6 and $115 \mathrm{~m}$. At water depths of $60 \mathrm{~m}$, represented by a 2.5 $\mathrm{m}$-long sediment core, the porewater ${ }^{14} \mathrm{C}_{\mathrm{DIC}}$ levels $(85-87 \mathrm{pMC})$ were lower than the corresponding sediment values in each layer (92-95 pMC), mainly due to the oxidation of relatively old organic matter (about $70 \mathrm{pMC}$ ) with no evidence to advection. In contrast, sediment cores from water depths shallower than $50 \mathrm{~m}$ showed only slight anaerobic oxidation and high ${ }^{14} \mathrm{C}_{\mathrm{DIC}}$ values of approximately $100 \mathrm{pMC}$, indicating possible downward advection. These geochemical observations support the perception that the penetration of seawater into the coastal aquifer occurs at the shallow water zone $(<50 \mathrm{~m})$, while further verification by deeper cores is required.

\section{INTRODUCTION}

Radiocarbon dating of groundwater and marine sediment porewater is subjected to alterations due to several diagenetic-biogeochemical and transport (advection/diffusion) processes. While several studies stressed the need for correction schemes for diagenetic processes affecting ${ }^{14} \mathrm{C}_{\mathrm{DIC}}$ levels of fresh groundwater (e.g. Mook 1980; Geyh 2000), it was only recently shown that in deep-sea sediments, diffusion of ${ }^{14} \mathrm{C}_{\mathrm{DIC}}$ from the bottom water into the sediments is the main process altering porewater ${ }^{14} \mathrm{C}_{\mathrm{DIC}}$ levels (Sivan et al. 2001, 2002). This process accounted for the gradual "rejuvenation" of porewater (up to $70 \%$ increase in ${ }^{14} \mathrm{C}_{\mathrm{DIC}}$ concentrations) compared to their hosting sediment. An opposite trend of "aging" ${ }^{14} \mathrm{C}_{\mathrm{DIC}}$ concentrations was observed in saline groundwater attributed to diagenetic processes (e.g. Mook 1980; Geyh 2000; Sivan et al. 2004).

This research aims to present the main processes affecting ${ }^{14} \mathrm{C}_{\mathrm{DIC}}$ concentrations in porewater at the shallow shelf (water depth less than $120 \mathrm{~m}$ ) off the Mediterranean coast of Israel. In contrast to the conditions in the deep sea, this area is subjected to heterogenic sediment composition, relatively high sedimentation rates, and possible advection. It is assumed that the potential zone of seawater penetration into the sediments (advection) toward the coastal aquifer is located in this region. This area was flooded by seawater some 18,000 yr ago (the end of the Last Glacial period), and seawater has intruded into coastal aquifers since then (e.g. Fairbanks 1989; Chappell et al. 1996). Examination of the diagenetic processes and ${ }^{14} \mathrm{C}_{\mathrm{DIC}}$ characteristics in this environment can help in assessing potential areas of seawater penetration. Moreover, such information may add to a better understanding of the chemical evolution and ${ }^{14} \mathrm{C}_{\mathrm{DIC}}$ values of the saline groundwater in the Israeli Mediterranean coastal aquifer $(60-70 \mathrm{pMC}$ at about $100 \mathrm{~m}$ from the shoreline and $50 \mathrm{~m}$ below sea level [Sivan et al. 2004]).

\footnotetext{
${ }^{1}$ Institute of Earth Sciences, Hebrew University, Jerusalem 91904, Israel.

${ }^{2}$ Geological Survey of Israel, Jerusalem 95501, Israel.

${ }^{3}$ Current address: Department of Earth and Planetary Sciences, Harvard University, 20 Oxford Street, Cambridge, Massachusetts 02138, USA. Email: sivan@fas.harvard.edu.

${ }^{4}$ Radiocarbon Dating Laboratory, ESER Dept. Weizmann Institute of Science, Rehovot 76100, Israel. Corresponding author. Email: elisabetta.boaretto@weizmann.ac.il

${ }_{5}^{5}$ Israel Oceanographic and Limnological Research, National Institute of Oceanography, Haifa 31080, Israel.
} 
In order to examine the biogeochemical processes, measurements of the chemical composition, ${ }^{14} \mathrm{C}_{\mathrm{DIC}}$, and stable carbon isotopic composition $\left(\delta^{13} \mathrm{C}_{\mathrm{DIC}}\right)$ were performed in several sediment cores (40-250 cm long) at water depths between 6 and $115 \mathrm{~m}$. As far as we know, this preliminary study contains the first set of data that combines ${ }^{14} \mathrm{C}_{\mathrm{DIC}}$ and major ion composition from short and intermediate cores in these shallow seawater sediments.

\section{METHODS}

Sediment cores (40-250 cm long) were collected at the shallow Mediterranean Israeli shelf (location in Table 1) at water depths between 6 and $115 \mathrm{~m}$. The cores were collected with a Benthos piston corer and a box corer (Ocean Instruments model $700 \mathrm{AL}$ ) for the relatively deeper sediments $(>40 \mathrm{~m}$ water depth), and in shallower waters by scuba divers using a Perspex mini-corer specially designed for this research. The cores were immediately sectioned and centrifuged under argon atmosphere to avoid contamination with atmospheric $\mathrm{CO}_{2}$, except the core at $46 \mathrm{~m}$ water depth, which was centrifuged in the laboratory. At shallower depths, the corer was designed to enable a fast separation into closed 10-cm compartments immediately after coring. Each compartment was connected to an argon tank and pressurized to squeeze the water out into a sealed syringe. Seawater samples were collected using Niskin or plastic bottles from about $1 \mathrm{~m}$ above the sea floor.

Seawater samples were analyzed for their chemical composition, ${ }^{14} \mathrm{C}_{\mathrm{DIC}}, \delta^{13} \mathrm{C}_{\mathrm{DIC}}$, and tritium activity. One surface seawater sample was analyzed for ${ }^{14} \mathrm{C}$ in the dissolved organic carbon $\left({ }^{14} \mathrm{C}_{\mathrm{DOC}}\right)$. Due to the low volume of porewater samples, they were not always analyzed for all parameters. The porewater sample was split for major ion analysis (about $2 \mathrm{~mL}$ ) and ${ }^{3} \mathrm{H}$ (only the large samples). Then, $20 \mathrm{~mL}$ was filtered using $0.45-\mu \mathrm{m}$ Nuclepore polycarbonate filters directly into plastic syringes containing $\mathrm{HgCl}_{2}$ powder for analyses of DIC $(1 \mathrm{~mL}), \mathrm{A}_{\mathrm{T}}(1 \mathrm{~mL}), \delta^{13} \mathrm{C}_{\mathrm{DIC}}$, and ${ }^{14} \mathrm{C}_{\mathrm{DIC}}$. The water samples were kept at $4{ }^{\circ} \mathrm{C}$ until the measurements.

Some of the sediment samples were dried at $30^{\circ} \mathrm{C}$ and then picked for shell and other inorganic carbonate material. In particular, well-preserved spines of sea urchin (Paracenstratus lividus) were identified and analyzed for stable and radioactive carbon isotopes composition $\left(\delta^{13} \mathrm{C}_{\mathrm{urc}}\right.$ and $\left.{ }^{14} \mathrm{C}_{\mathrm{urc}}\right)$. Analysis by scanning electron microscopy (SEM) showed that the sea urchin spines from the core were in a very good state of preservation.

\section{Analytical Methods}

Major ions were analyzed using standard methods with precision of less than 3\%. DIC was measured in a newly developed system, designed by Sass and Lazar (the Hebrew University, Israel, unpublished), which is able to analyze small volumes $(1 \mathrm{~mL})$ at an accuracy better than $1 \%$. The water samples were acidified with concentrated $\mathrm{HCl}$ to transform total inorganic carbon to $\mathrm{CO}_{2}$ gas, which was measured by an NDIR analyzer (LiCor 6252). Total alkalinity was measured on $0.50-\mathrm{mL}$ samples by Gran titration (Stumm and Morgan 1996) using a micro-pH electrode (Orion 9863BN). The error, calculated by averaging numerous duplicate samples, was \pm 0.03 meq $\mathrm{L}^{-1}$.

${ }^{3} \mathrm{H}$ (tritium) was analyzed by a LKB 1220 Quantulus scintillation counter in the Weizmann Institute. Tritium concentrations are expressed in tritium units $\left(1 \mathrm{TU}=1\right.$ atom of ${ }^{3} \mathrm{H}$ per $10^{18}$ atoms of hydrogen [Faure 1986]), and the counting error was $\pm 0.3 \mathrm{TU} . \delta^{13} \mathrm{C}_{\mathrm{DIC}}$ and ${ }^{14} \mathrm{C}_{\mathrm{DIC}}$ analyses were performed on inorganic $\mathrm{CO}_{2}$ extracted from each water sample (Boaretto et al. 1998). A fraction of the extracted $\mathrm{CO}_{2}$ was used for $\delta^{13} \mathrm{C}_{\mathrm{DIC}}$ measurement by conventional mass spectrometry. Another fraction was converted to graphite for ${ }^{14} \mathrm{C}_{\mathrm{DIC}}$ determination at the Weizmann Institute according to Boaretto et al. (1998). ${ }^{14} \mathrm{C}$ measurements were performed at the Accelerator Mass Spectrometry 
(AMS) Radiocarbon Dating Lab at Aarhus University (Denmark) and at the NSF-AMS Laboratory, Tucson (Arizona). ${ }^{14} \mathrm{C}_{\mathrm{DOC}}$ was performed on organic $\mathrm{CO}_{2}$ extracted and measured in Tucson according the procedure of Burr et al. (2001). The analyses of ${ }^{14} \mathrm{C}_{\text {urc }}$ were also performed in Tucson. $\delta^{13} \mathrm{C}$ is reported on the PDB scale and its precision is $\pm 0.1 \%$. The activity of ${ }^{14} \mathrm{C}$ is given in pMC (percent Modern Carbon) according to the international convention (Stuiver and Polach 1977). The precision of the measurement is $\pm 0.5 \mathrm{pMC}$.

\section{RESULTS AND DISCUSSION}

The chemical and the isotopic compositions of the bottom seawater and the porewater samples are given in Table 1.

Here, we test only the results from the upper $250-\mathrm{cm}$ sediments in order to compare the different sites. The chemical profiles of $\mathrm{Cl}^{-}, \mathrm{Na}^{+}$, and $\mathrm{Mg}^{2+}$ in porewater slightly varied between sites, but in general, showed conservative behavior with respect to the bottom seawater concentrations (Figure 1). On the other hand, $\mathrm{SO}_{4}{ }^{2-}$, total alkalinity, $\mathrm{DIC}, \mathrm{Ca}^{2+}$, and $\mathrm{Sr}^{2+}$ showed non-conservative behavior along the cores (Figure 2). $\mathrm{Ca}^{2+}$ and $\mathrm{Sr}^{2+}$ (Figure $2 \mathrm{a}$ and $2 \mathrm{~b}$, respectively) were constant along the core in some sites and in the others showed slight decrease or slight increase with sediment depth (with no correlation to water depth), indicating precipitation/dissolution of $\mathrm{CaCO}_{3} \cdot \mathrm{SO}_{4}{ }^{2-}$ slightly decreased in porewater at shallow water depths $(<50 \mathrm{~m})$, where the sediment is composed mainly from sand and silt. In deeper water depths (62-m core), where the sediments are composed mainly by clay, the gradient was much steeper (Figure $2 \mathrm{c}$ ). In this case, $\mathrm{SO}_{4}{ }^{2-}$ decreased by $30 \mathrm{meq} / \mathrm{L}$ along the top $250 \mathrm{~cm}$ (Figure 2c). The decrease was probably due to anaerobic oxidation of organic matter by sulfate reduction and maybe involved also other processes as well. The anaerobic oxidation is supported by the increase in the alkalinity and DIC (Figure 2d, e). The close values of total alkalinity and DIC indicate that the alkalinity is mostly from carbonates. The ratio between the alkalinity and DIC (Figure 3) is between 1 (in the 62-m core) to 1.5 in other cores. This indicates that the main process is sulfate reduction, resulting in a 1:1 ratio (aerobic oxidation would increase only the DIC without changing the alkalinity) combined with minor $\mathrm{CaCO}_{3}$ precipitation/dissolution, giving a 2:1 ratio. Other processes might be involved in the sediments at about $60 \mathrm{~m}$ water depth, since the increase of the DIC and the alkalinity by $15 \mathrm{mM}$ (and $15 \mathrm{meq} / \mathrm{L}$ if the alkalinity is mainly carbonatic) is not balanced by the decrease of the $\mathrm{SO}_{4}{ }^{2-}$ by $30 \mathrm{meq} / \mathrm{L}$. The processes might involve other diagenetic processes and different diffusion fluxes of these parameters.

The stable isotopic composition of the inorganic carbon $\left(\delta^{13} \mathrm{C}_{\mathrm{DIC}}\right)$ at the $62-\mathrm{m}$ core became lighter with depth of sediment to a value of $-15 \%$ PDB at the bottom of the core (Figure $4 \mathrm{a}$ ). These values are close to the levels of organic matter $\left(\delta^{13} \mathrm{C}_{\mathrm{SOC}}\right)$ in deep-sea sediments (Sivan et al. 2002). The porewater $\delta^{13} \mathrm{C}_{\mathrm{DIC}}$ values are consistent with intensive anaerobic oxidation. The addition of $15 \mathrm{mM}$ DIC from the decomposition of organic matter of $-16 \%$ PDB to $2.5 \mathrm{mM}$ DIC of seawater origin $(0 \%$ PDB $)$ would yield DIC with about $-14 \%$ PDB $[2.5 \times(0 \%)+15 \times(-16 \%)=17.5 \times(-14 \%)]$, similar to the values measured in the deep porewater (Figure $4 \mathrm{a})$. The $\delta^{13} \mathrm{C}$ values of the carbonate $\left(\delta^{13} \mathrm{C}_{\text {urc }}\right)$ were close to the seawater values as expected (Figure $\left.4 \mathrm{a}\right)$.

Tritium was sampled in 4 sites at the top $20 \mathrm{~cm}$ of the sediments (Table 1). The values show that the age of the porewater at the top of the sediments is the same as present-day seawater. The ${ }^{14} \mathrm{C}_{\mathrm{DIC}}$ profiles (Figure $4 \mathrm{~b}$ ) support this conclusion. The top $50 \mathrm{~cm}$ of all cores had ${ }^{14} \mathrm{C}_{\mathrm{DIC}}$ levels similar to present-day seawater (around $100 \pm 10 \mathrm{pMC}$ ). Below $50 \mathrm{~cm}$, the ${ }^{14} \mathrm{C}_{\mathrm{DIC}}$ values were different at the 2 long cores (62 m and $46 \mathrm{~m}$ ). ${ }^{14} \mathrm{C}_{\mathrm{DIC}}$ values were high and similar to seawater values all along the $46-\mathrm{m}$ core; whereas, in the $62-\mathrm{m}$ core, they decreased with depth to $85 \mathrm{pMC}$ at the bottom of the 


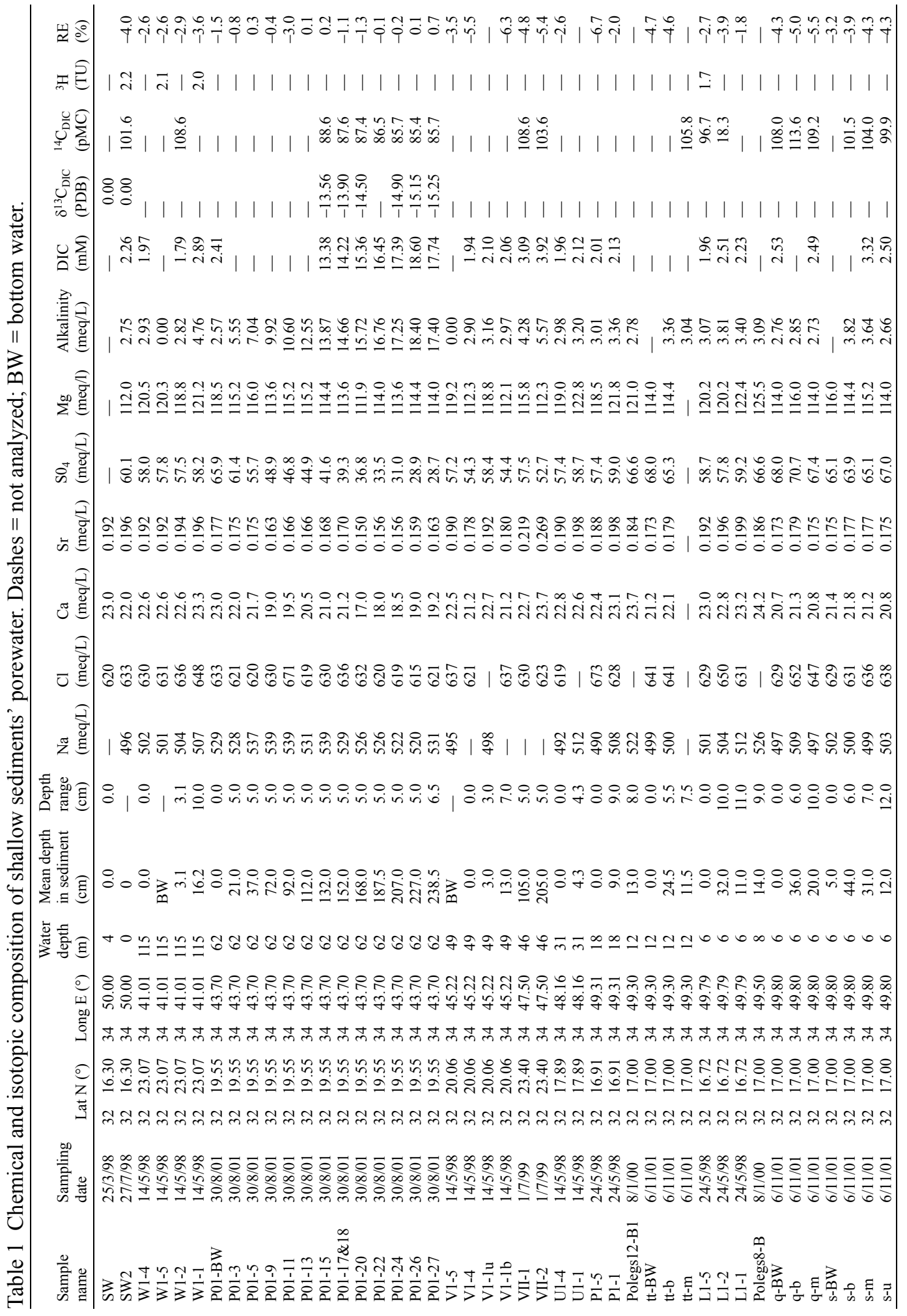



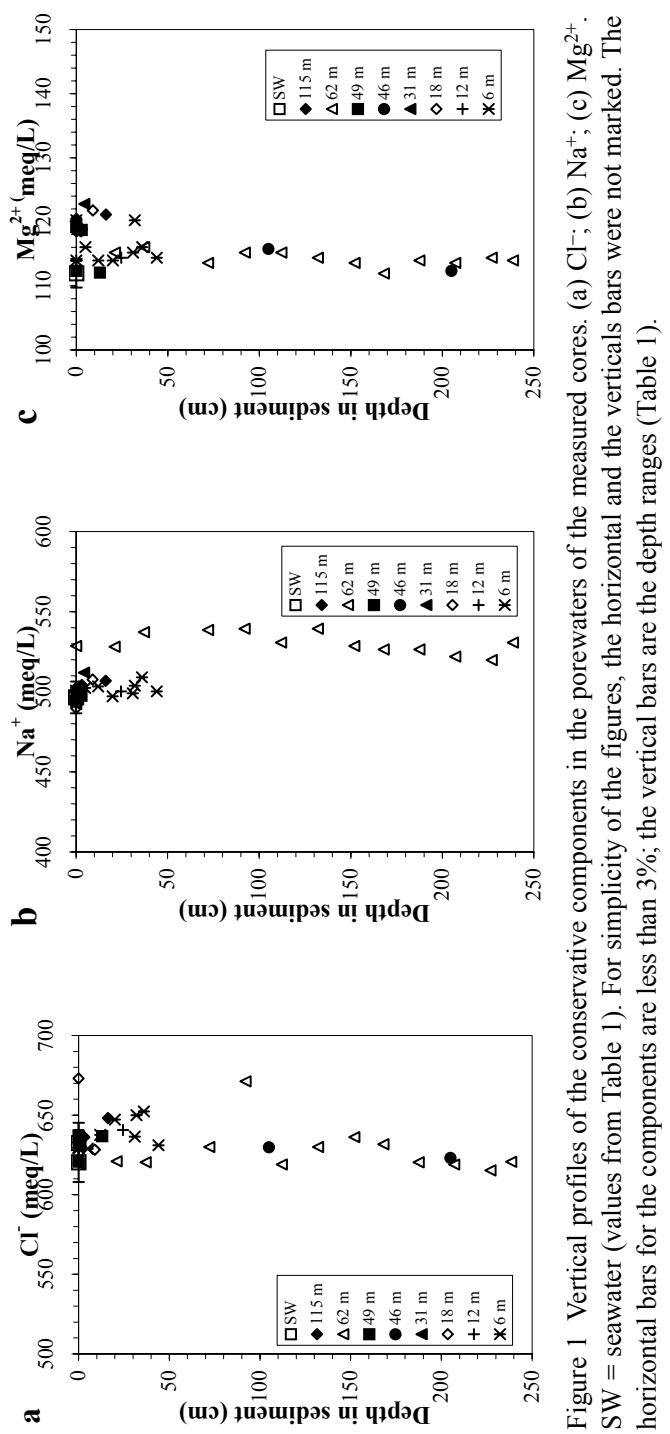

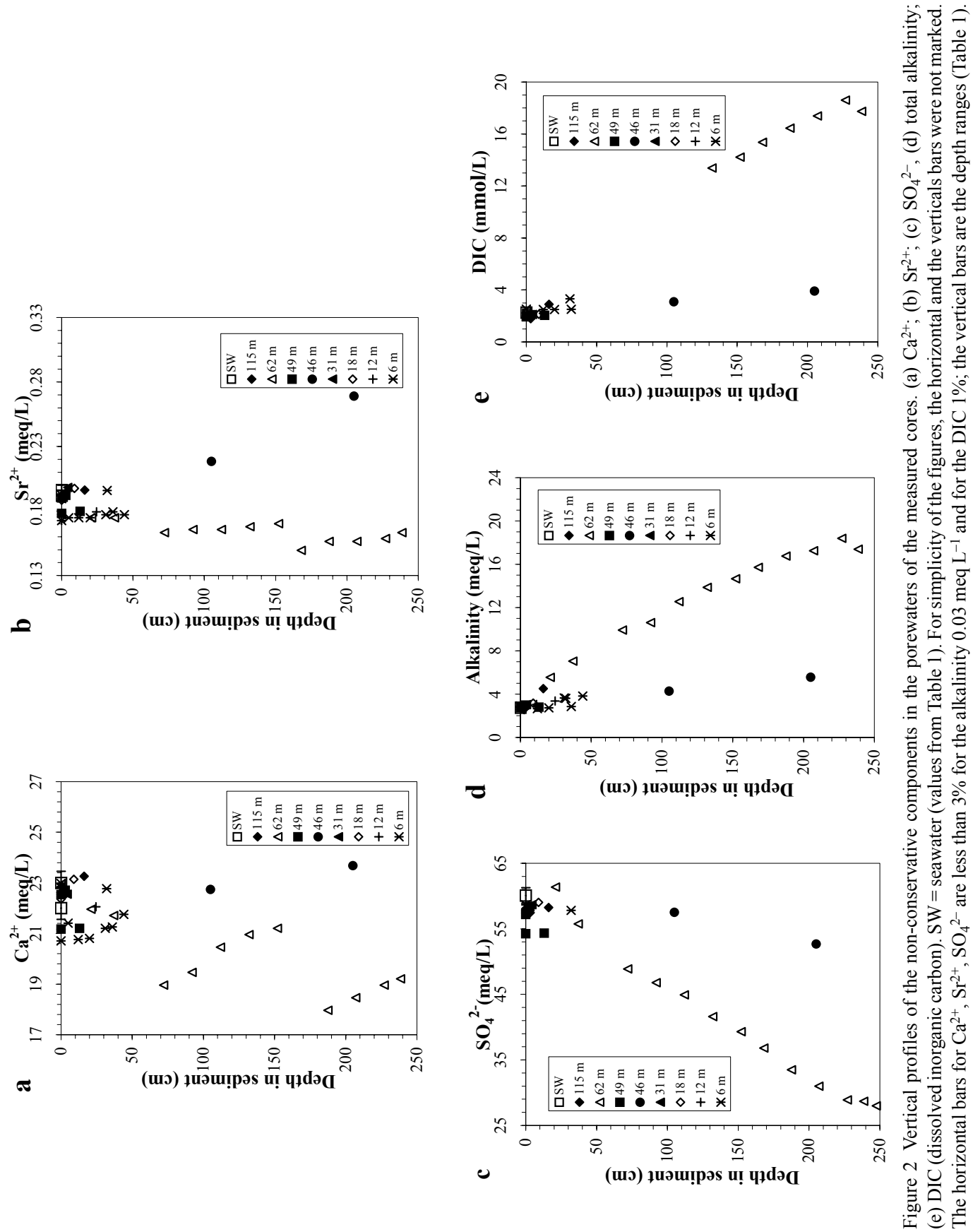


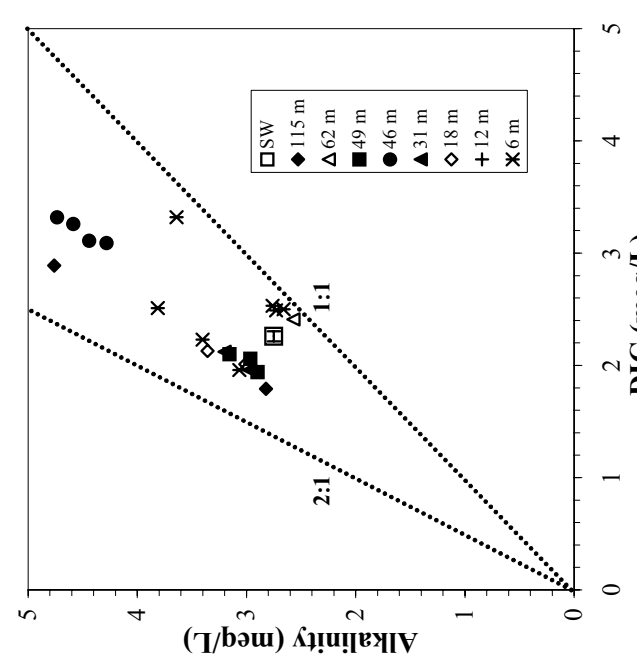

舀宗

可高

这 क

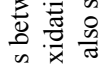

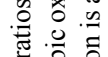

击

tri

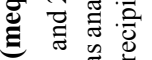

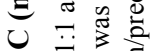

西

응

紊

$\Xi \Xi$

马.

च :

ช.

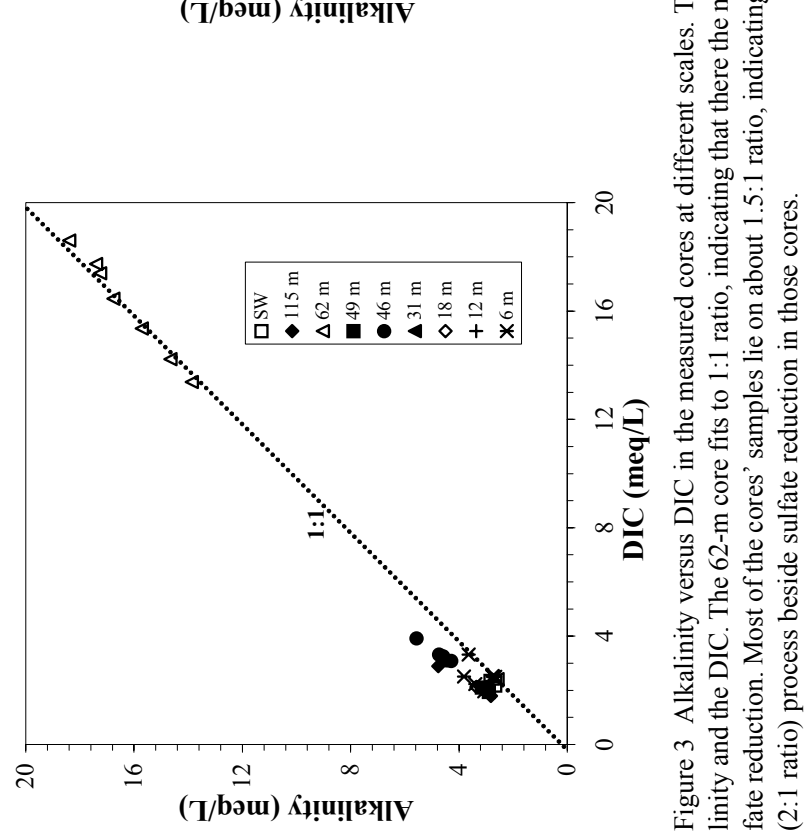


$\boldsymbol{a}$ $\delta^{13} \mathrm{C}(\% \mathrm{PDB}) \quad$ b
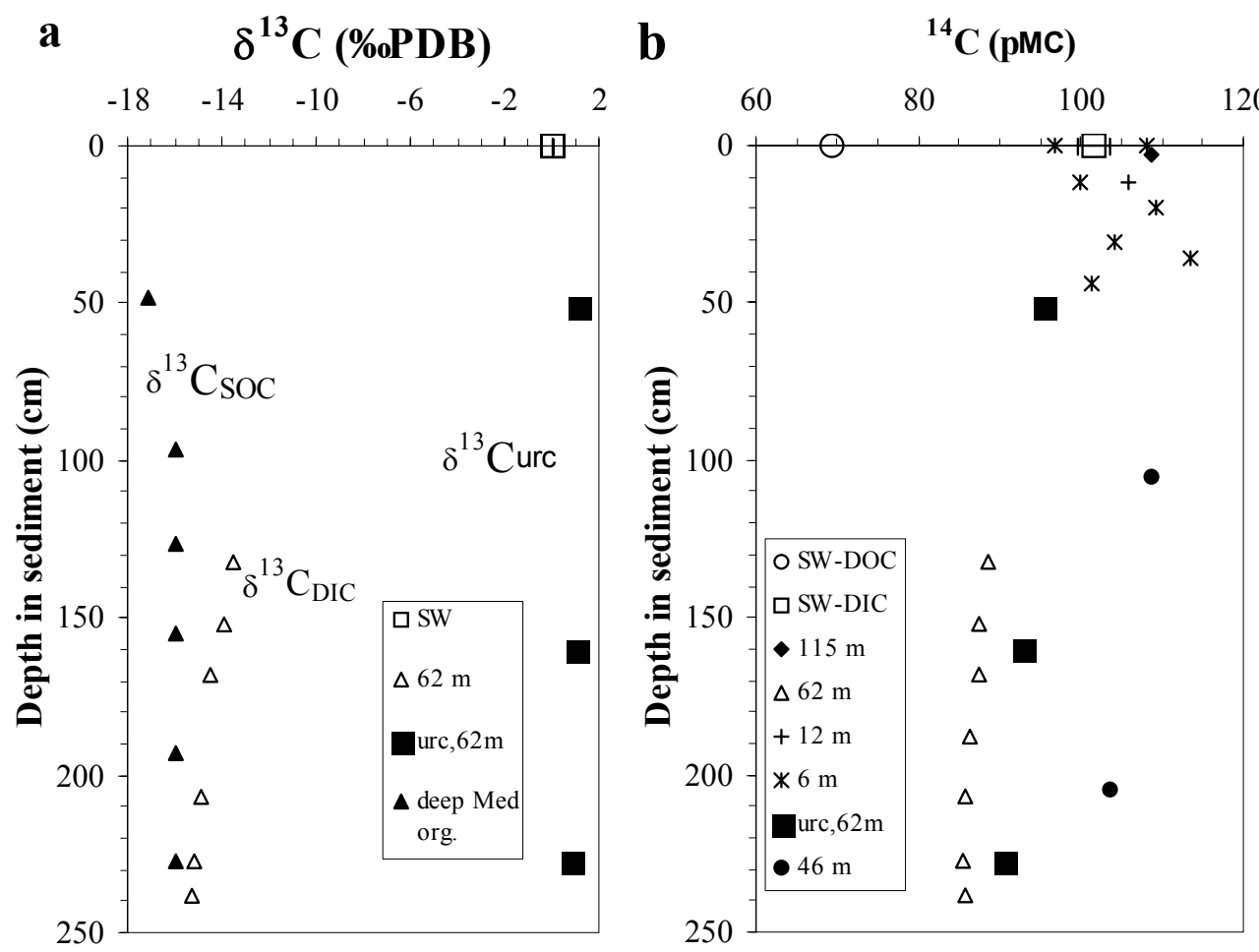

Figure 4 (a) Vertical profile of $\delta^{13} \mathrm{C}_{\mathrm{DIC}}$ and $\delta^{13} \mathrm{C}_{\mathrm{urc}}$ (sea urchin spine) at the 62-m water depth core. A vertical profile of $\delta^{13} \mathrm{C}_{\mathrm{SOC}}$ (SOC-sediments' organic carbon) in the deep Mediterranean is also presented (data from Sivan et al. 2002) as well as the values of $\delta^{13} \mathrm{C}_{\mathrm{DIC}}$ of the seawater (SW, Table 1). (b) ${ }^{14} \mathrm{C}_{\mathrm{DIC}}$ profiles at the measured cores and ${ }^{14} \mathrm{C}_{\text {urc }}$ at the 62 -m water depth core. Also, the surface seawater values of ${ }^{14} \mathrm{C}_{\mathrm{DIC}}$ (black square) and the ${ }^{14} \mathrm{C}_{\mathrm{DOC}}$ (grey square) are presented. In both graphs, the horizontal bars are smaller than the symbols and the vertical bars (not marked) are the depth ranges (Table 1).

core. The present-day porewater ${ }^{14} \mathrm{C}_{\mathrm{DIC}}$ levels at the 46 -m core indicate that the slight anaerobic oxidation of organic matter with values lower than $100 \mathrm{pMC}$ (assumed value, not measured due to technical problems) and the slight $\mathrm{CaCO}_{3}$ dissolution had a minor effect on ${ }^{14} \mathrm{C}_{\mathrm{DIC}}$ values. According to Sivan et al. (2002), diffusion alone is not capable of enhancing the ${ }^{14} \mathrm{C}_{\mathrm{DIC}}$ to values measured at the core bottom $(250 \mathrm{~cm})$. We speculate that such relatively high ${ }^{14} \mathrm{C}_{\mathrm{DIC}}$ values indicate advection of seawater into the sediment at this site.

On the other hand, at the $62-\mathrm{m}$ site, porewater ${ }^{14} \mathrm{C}_{\mathrm{DIC}}$ levels $(85-87 \mathrm{pMC})$ were lower than seawater values and the corresponding sediment carbonate $\left({ }^{14} \mathrm{C}_{\text {urc }}\right)$ in each layer $(92-95 \mathrm{pMC}$, Figure $4 \mathrm{~b})$. The shift of ${ }^{14} \mathrm{C}_{\mathrm{DIC}}$ values in porewater to values lower than their sediment host probably resulted from the anaerobic oxidation of relatively old organic matter (about $70 \mathrm{pMC}$, calculated from a rough mass balance). The organic matter was not analyzed for ${ }^{14} \mathrm{C}$ as mentioned above, but ${ }^{14} \mathrm{C}_{\mathrm{DOC}}$ in seawater in this area was measured as about $70 \mathrm{pMC}$. This value might be correlated to the organic matter values; the correlation between $\delta^{13} \mathrm{C}_{\text {DIC }}$ and ${ }^{14} \mathrm{C}_{\text {DIC }}$ (Figure 5) supports the possibility. It seems that DIC derived from the oxidation of organic matter reduces both ${ }^{14} \mathrm{C}_{\mathrm{DIC}}$ and $\delta^{13} \mathrm{C}_{\mathrm{DIC}}$ values. We would like to mention that the values of the sediments (92-95 pMC) probably represent the true ages of the layers. The good preservation of the sea urchin spine suggests that the spine was deposited shortly after the death of the animal. On the other hand, the shells fragments can be much older than the sediment layer. For example, shells collected from some Israeli beaches can be several thousand years older (E Boaretto, personal communication). 


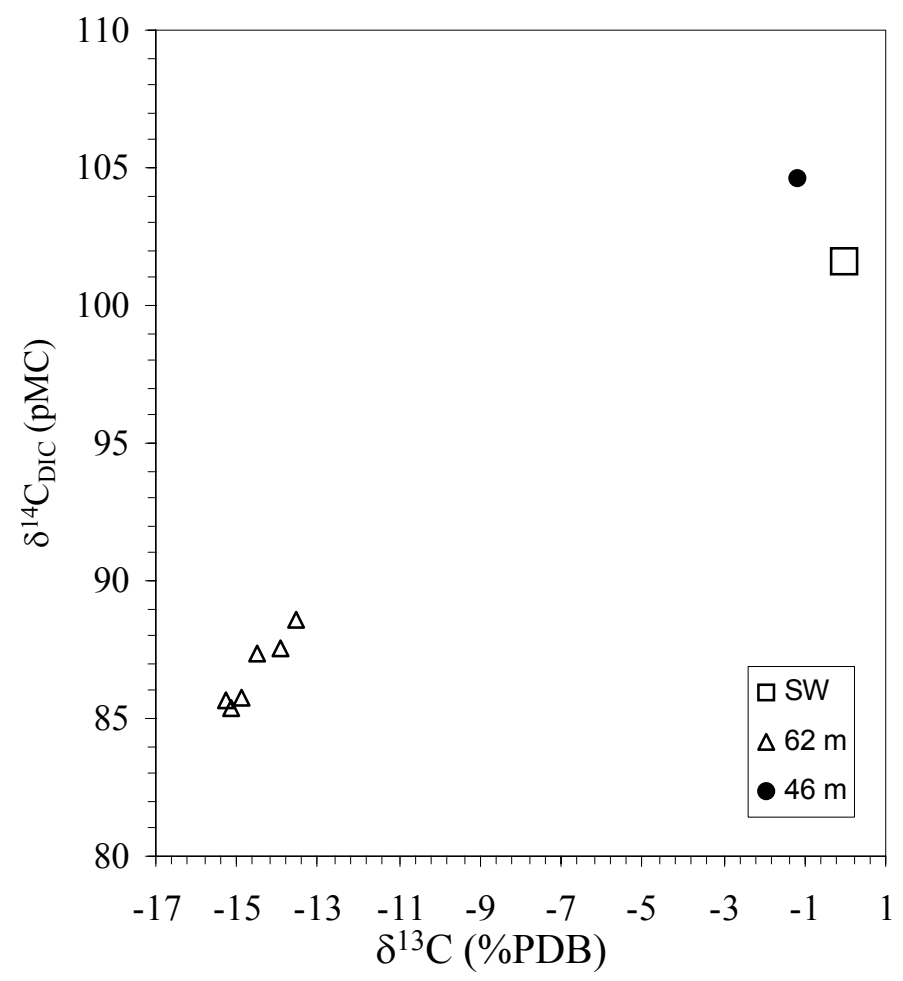

Figure $5{ }^{14} \mathrm{C}_{\mathrm{DIC}}$ versus $\delta^{13} \mathrm{C}_{\mathrm{DIC}}$ at the $46-\mathrm{m}$ and the $62-\mathrm{m}$ water depth cores and in the seawater (SW). The horizontal and vertical bars are smaller than the symbols.

In general, the porewater ${ }^{14} \mathrm{C}_{\mathrm{DIC}}$ characteristics showed a threshold between $\sim 45$ to $\sim 60 \mathrm{~m}$ water depth. In the 62-m area, there is evidence of intensive anaerobic oxidation of organic matter (with ${ }^{14} \mathrm{C}$ values of $70 \mathrm{pMC}$ ) by sulfate reduction and slight $\mathrm{CaCO}_{3}$ precipitation with no evidence of advection. The shallower sites showed much less anaerobic oxidation of organic matter and no or even slight dissolution of $\mathrm{CaCO}_{3}$. In the 46-m site, there might be an evidence for fast advection of seawater into the sediments. In order to better validate this evidence, further study is suggested in this shallow sediment system by deeper coring and hydrological modeling.

The above results contribute to a better understanding of the saline groundwater age in the Israeli Mediterranean coastal aquifer. The saline waters in this aquifer contain relatively low ${ }^{14} \mathrm{C}_{\mathrm{DIC}}$ values (60-70 pMC), mainly attributed to slightly DIC enrichment from the anaerobic oxidation of "dead" organic matter (Sivan et al. 2004). We think that these groundwaters are originated from porewater that has penetrated the aquifer from the shallow water zone $(<50 \mathrm{~m}$ depth), where indeed there is evidence for advection and slight oxidation of organic matter, and its ${ }^{14} \mathrm{C}_{\mathrm{DIC}}$ value is reduced only below the young marine (post-glacial) sediments, when it reaches the Pleistocene aquifer.

\section{ACKNOWLEDGEMENTS}

This work was supported by the Israel Science Foundation Grant 674/97, and partially by the Israeli Ministry of Infrastructure. We are grateful to the crew of the R/V Shikmona for their work at sea. We would like thank Y Gertner and Y Bishop from the Israel Oceanographic and Limnological Research and H Hemo from the Geological Survey for their help in carrying out the sampling at sea. 
Thanks to D Gil from the Geological Survey for collecting one of the cores (46 m) and to O Yoffe and D Stiber from the Geological Survey for the chemical analyses. Special thanks to S Weiner from the Weizmann Institute for the SEM analysis of the Paracenstratus lividus and to G Mintz for the ${ }^{14} \mathrm{C}$ preparation and ${ }^{3} \mathrm{H}$ analyses at the Weizmann Institute.

\section{REFERENCES}

Boaretto E, Thorling L, Sveinbjörnsdóttir AE, Yechieli Y, Heinemeier J. 1998. Study of the effect of fossil organic carbon on ${ }^{14} \mathrm{C}$ in groundwater from Hvinningdal, Denmark. Radiocarbon 40(2):915-20.

Burr GS, Thomas JM, Reines D, Jeffrey D, Courtney C, Jull AJT, Lange T. 2001. Sample preparation of dissolved organic carbon in groundwater for AMS ${ }^{14} \mathrm{C}$ analysis. Radiocarbon 43(1):183-90.

Chappell J, Omura A, Esat T, McCulloch M, Pandolfi J, Ota Y, Pillans B. 1996. Reconciliation of late Quaternary sea levels derived from coral terraces at Huon Peninsula with deep sea oxygen isotope records. Earth and Planetary Science Letters 141:227-36.

Fairbanks RG. 1989. A 17,000-year lacio-eustatic sea level record: influence of glacial melting rates on the Younger Dryas event and deep-ocean circulation. Nature 342:637-42.

Faure G. 1986. Principles of Isotope Geology. New York: John Wiley \& Sons.

Geyh MA. 2000. An overview of ${ }^{14} \mathrm{C}$ analysis in the study of groundwater. Radiocarbon 42(1):99-114.
Mook WG. 1980. Carbon-14 in hydrogeological studies. In: Frits P, Fontes J Ch, editors. Handbook of Environmental Isotope Geochemistry. Volume 1. The Terrestrial Environment. New York: Elsevier Scientific Publishers. p 49-74.

Sivan O, Lazar B, Yechieli Y, Boaretto E, Heinemeier J, Herut B. $2002 .{ }^{14} \mathrm{C}$ excess in deep-sea sediments porewater driven by diffusion - southeast Mediterranean. Limnology and Oceanography 47:565-70.

Sivan O, Herut B, Yechieli Y, Lazar B. 2001. Radiocarbon dating of porewater - correction for diffusion and diagenetic processes. Radiocarbon 43(2B):765-71.

Sivan O, Yechieli Y, Herut B, Lazar B. 2004. Geochemical evolution and timescale of seawater intrusion into the coastal aquifer of Israel. Geochimica et Cosmochimica Acta. (submitted).

Stuiver M, Polach HA. 1977. Discussion: reporting of ${ }^{14} \mathrm{C}$ data. Radicarbon 19(3):355-63.

Stumm W, Morgan JJ. 1996. Aquatic Chemistry. New York: John Wiley \& Sons. 